\title{
A Study into the Demographics Having the Greatest Carbon Footprint
}

Tony Xu and Shayan Khalili

Earl Haig Secondary School

\begin{abstract}
Our aim was to determine factors predicting greenhouse gas emissions per capita and to identify the demographics having the greatest carbon footprint. The relationship between socioeconomic trends and greenhouse gas emissions is controversial, given that many past studies evaluated only a single factor. We analyzed the relationship between global greenhouse gas emissions per capita and literacy rate, GDP per capita, urban population percentage, adolescent fertility rate, unemployment percentage, percent of agricultural land, research and development expenditure, renewable energy consumption, food production, population growth, mobile cellular subscriptions, air transport freight, and forest area. We gathered data from 217 countries spanning a period of 20 years; 1993 to 2012. We analyzed the data using multiple regression models. We concluded food production, renewable energy consumption, air transport, mobile cellular subscriptions, literacy rate, and population growth have the greatest impact on predicting greenhouse gas (GHG) emissions in our model, suggesting the demographic with the greatest carbon footprint are wealthy, educated people living in urban centers.
\end{abstract}

\section{KEYWORDS}

Climate change, greenhouse gas, carbon footprint, data science

\section{INTRODUCTION}

Greenhouse gas (GHG) emissions are the biggest contributor to climate change and global warming, especially since the start of the industrial era. Atmospheric carbon dioxide concentrations have risen from $280 \mathrm{ppm}$ to $400 \mathrm{ppm}$ in the past 150 years [1], and combined with the rises in concentrations of other greenhouse gases, has caused a $0.85 \mathrm{C}$ (global mean) increase from 1880 to 2012 [1]. Although many studies have assessed greenhouse gas emissions and its relationship with climate change [1] [2] [3], socioeconomic trends in relation with greenhouse gas emissions are not well studied. Our aim was to determine which demographics produce the most greenhouse gases, and therefore propose policies to minimize the average greenhouse gas emissions per capita. Unlike past studies looking at a single or a few factors [4] [5] [6] [7] [8] [2] [9], this study analyzes 13 factors to compare and contrast their respective relationships with GHG per capita. The 13 factors analyzed were: literacy rate, GDP per capita, rural population percentage, urban population percentage, adolescent fertility rate (births per 1000 women ages 15 - 19), unemployment percentage, percent of agricultural land, renewable energy consumption (\% of final energy consumption), food production index, population growth (annual \%), mobile cellular subscriptions, air transport freight, and forest area (\% of total area). We picked these 13 factors because they had data spanning 20 years and are unique indicators under different World Bank categories [10] of economic and social development. We predict literacy rate, GDP per capita, and adolescent fertility will have the largest impacts on GHG emissions per capita because we hypothesize citizens of wealthier countries have greater access to resources and can afford to be more wasteful.

\section{METHODOLOGY}

We used the Python library, Pandas, to structure the data and SAS Visual Analytics [14] to assess the relationship between greenhouse gas (GHG) emissions per capita and 13 factors [1]. We extracted data spanning a 20-year period from 1993 to 2012 from the World Bank database for each factor [10] . We also extracted the total GHG emissions and global population datasets to calculate GHG emissions per capita. Using a Python library 
called Pandas, we combined these two into a structure called a DataFrame. Iterating through each year in the DataFrame, we divided the GHG emission figure for the particular year by the year's population and multiplied by 1000 to convert the units from kilotons of GHG per capita to tons of GHG per capita. We then joined the tables and ran regression models using SAS Visual Analytics and scikit-learn [15] to determine if correlations exist between GHG emissions per capita and each factor. We quantified the strength of each correlation using the impact weights generated by our regression model. We used a 3:1 ratio for our training and testing set.

\section{RESULTS}

\begin{tabular}{lcc}
\hline & GHG per capita (real) & GHG per capita (prediction) \\
\hline $\mathbf{1 9 9 5}$ & 6.837476 & 7.564140 \\
$\mathbf{2 0 0 5}$ & 7.245037 & 7.148353 \\
1996 & 6.777399 & 7.300522 \\
$\mathbf{2 0 0 1}$ & 6.513074 & 6.732983 \\
1994 & 6.899806 & 7.321203
\end{tabular}

Figure 1. Predictions from the multiple regression model

With an $r 2$ value of 0.997 , our model shows a strong correlation between the 13 indicators and GHG emissions per capita. Proceeding with testing the regression model, we can see in Figure 1 that the model produced results close to the actual GHG emission per capita output.

\begin{tabular}{|c|c|c|c|c|c|c|c|c|c|c|c|c|c|}
\hline & $\begin{array}{l}\text { Agricultural } \\
\text { land }\end{array}$ & $\begin{array}{l}\text { Forest } \\
\text { area }\end{array}$ & $\begin{array}{l}\text { Food } \\
\text { production }\end{array}$ & $\begin{array}{l}\text { Renewable } \\
\text { energy } \\
\text { consumption }\end{array}$ & $\begin{array}{l}\text { Air } \\
\text { transport }\end{array}$ & $\begin{array}{l}\text { Mobile } \\
\text { cellular } \\
\text { subscriptions }\end{array}$ & $\begin{array}{l}\text { GDP per } \\
\text { capita }\end{array}$ & $\begin{array}{l}\text { Literacy } \\
\text { rate }\end{array}$ & Unemployment & $\begin{array}{l}\text { Fertility } \\
\text { rate }\end{array}$ & $\begin{array}{l}\text { Population } \\
\text { growth }\end{array}$ & $\begin{array}{l}\text { Rural } \\
\text { population }\end{array}$ & $\begin{array}{l}\text { Urban } \\
\text { population }\end{array}$ \\
\hline $\begin{array}{l}\text { Agricultural } \\
\text { and }\end{array}$ & 1 & -0.2509 & 0.04036656 & 0.20593454 & 0.077884 & -0.13520355 & -0.1 & 0.32 & 249 & -0.3189 & -0.3 & -0.04 & 0.04 \\
\hline $\begin{array}{l}\text { Forest } \\
\text { area }\end{array}$ & -0.250908 & 1 & -0.9656218 & 0.64576591 & -0.97093 & -0.89173926 & -0.86987 & -0.98979 & -0.262344972 & 0.994294 & + 0.988629203 & 0.971059142 & -0.971059 \\
\hline $\begin{array}{l}\text { Food } \\
\text { production }\end{array}$ & 0.0403666 & -0.9656 & 1 & -0.65822832 & 0.989691 & 0.976857072 & 0.964818 & 0.941793 & 0.085595542 & -0.94548 & $\begin{array}{l}3 \\
-0.923287762\end{array}$ & -0.99829437 & 0.998294 \\
\hline $\begin{array}{l}\text { Renewable } \\
\text { energy } \\
\text { consumption }\end{array}$ & 0.2059345 & 0.6458 & -0.6582283 & 1 & -0.65083 & -0.62460211 & -0.67114 & -0.58109 & 0.203056035 & 0.60508 & $\begin{array}{ll}3 & 0.607003787\end{array}$ & 0.676119976 & -0.6761 \\
\hline Air transport & 0.0778836 & -0.9709 & 0.98969055 & -0.65082552 & 1 & 0.953528965 & 0.939518 & 0.951921 & 0.135353907 & -0.95617 & $\begin{array}{l}7 \\
7\end{array}$ & -0.98830226 & 0.988302 \\
\hline $\begin{array}{l}\text { Mobile cellular } \\
\text { subscriptions }\end{array}$ & -0.135204 & -0.8917 & 0.97685707 & -0.62460211 & 0.953529 & 1 & 0.984884 & 0.859109 & -0.036703319 & -0.85921 & -0.829061207 & -0.97228335 & 0.972283 \\
\hline $\begin{array}{l}\text { GDP per } \\
\text { capita }\end{array}$ & -0.153127 & -0.8699 & 0.96481801 & -0.67114274 & 0.939518 & 0.984884198 & 1 & 0.830173 & -0.12901091 & -0.83983 & -0.798087407 & -0.95651476 & 0.9565148 \\
\hline Literacy rate & 0.326422 & -0.9898 & 0.94179346 & -0.58109239 & 0.951921 & 0.85910886 & 0.830173 & 1 & 0.315307582 & -0.98712 & -0.986103613 & -0.94601475 & 0.9460147 \\
\hline Unemployment & 0.5959992 & -0.2623 & 0.08559554 & 0.203056035 & 0.135354 & -0.03670332 & -0.12901 & 0.315308 & 1 & -0.3233 & -0.365163284 & -0.10913837 & 0.1091384 \\
\hline Fertility rate & -0.318902 & 0.9943 & -0.9454827 & 0.605080056 & -0.95617 & -0.85920718 & -0.83983 & -0.98712 & 044 & 1 & 0.990784702 & 0.950655133 & -0.9506551 \\
\hline $\begin{array}{l}\text { Population } \\
\text { growth }\end{array}$ & -0.355566 & 0.9886 & -0.9232878 & 0.607003787 & -0.93342 & -0.82906121 & -0.79809 & -0.9861 & -0.365163284 & 0.990785 & 1 & 0.931198099 & -0.9311981 \\
\hline $\begin{array}{l}\text { Rural } \\
\text { population }\end{array}$ & -0.040759 & 0.9711 & -0.9982944 & 0.676119976 & -0.9883 & -0.97228335 & -0.95651 & -0.94601 & -0.109138371 & 0.950655 & 0.931198099 & 1 & - \\
\hline $\begin{array}{l}\text { Urban } \\
\text { population }\end{array}$ & 0.0407593 & -0.9711 & 0.99829437 & -0.67611998 & 0.988302 & 0.972283347 & 0.956515 & 0.946015 & 0.109138371 & -0.95066 & -0.931198099 & -1 & \\
\hline
\end{tabular}

Figure 3. Correlation matrix of Pearson correlation coefficient for the factors

Model Weights

Agricultural land (\% of land area)

1.161289e-01

Forest area (\% of land area)

$2.988346 \mathrm{e}+00$

Food production index $(2004-2006=100)$

$-5.358055 e+00$

Renewable energy consumption ( $\%$ of total final

5.812910e-02 energy consumption)

Air transport, freight (million ton-km)

$5.707205 \mathrm{e}-01$

Mobile cellular subscriptions (per 100 people)

$-5.052614 \mathrm{e}-01$

GDP per capita (current US\$)

$1.199155 \mathrm{e}+00$

Literacy rate, adult total (\% of people ages 15 and above)

6.772573e-01

Unemployment, total (\% of total labor force) (modeled ILO estimate)

$-1.297599 e-01$

Fertility rate, total (births per woman)

$-1.659450 e+00$

Population growth (annual \%)

$6.060881 \mathrm{e}-02$

Rural population (\% of total population)

$-5.595735 e+12$

Urban population (\% of total population)

$-5.595735 e+12$

Figure 2. Weights generated by the multiple regression model

Figure 3 is a correlation matrix of our factors, it shows factors are not independent. This is significant because our model could be simplified by removing factors which have high Pearson's $\mathrm{R}$ with other factors.

\section{DISCUSSION}

Based on the standardized weights produced by our model, we found the indicators with the greatest impact on GHG emissions per capita are food production, renewable energy consumption, 
air transport, mobile cellular subscriptions, literacy rate, and population growth. We correctly predicted literacy rate as having a large impact, but GDP per capita and adolescent births did not have as large of an impact as we predicted. However, we believe the results still suggest our assumptions are correct as it can be extrapolated that wealthy educated people living in urban centers pollute the most.

Literacy rate is correlated with higher education. A more educated populace tends to be wealthier. Wealthier people have more discretionary income to spend on luxury goods and services and tend to be more urbanized. It can be extrapolated people living in cities have easier and greater access to goods and services. Moreover, increased urbanization reduces carbon sinks. Thus, urban population growth also has a strong weight.

The correlation between food production and greenhouse gas emissions is likely due to an increasing global population and increasing standards of living [13]. Agriculture accounts for onethird of total anthropogenic GHG emissions [12].

As the world becomes more urbanized and wealthier, the demand for tourism and the transportation of food and goods increases. Current large-scale transportation methods burn fossil fuels and emit greenhouse gases. Hence, there is a strong correlation between air freight and GHG emissions.

This study matched findings from previous research [4] [5] [6] [7] [8] [2] [9] which studied the relationship between food production, irrigation, urbanization, air freight, and greenhouse gas emissions.

A weakness of our study is correlation does not imply causation. Moreover, data did not exist for some underdeveloped countries, possibly skewing the global average. Countries which made up each data set can be found here [10]. Unfortunately, each factor did not have the same number of countries so there were differing number of data points between regression analyses. Future studies should aim to determine if the correlations are causal. Due to the impracticalities of conducting controlled experiments, future studies could analyze temporal precedence to more accurately determine if a factor caused an increase in GHG emissions per capita. It would also be interesting for future studies to investigate if wealthier countries' investments in renewable energy mitigate their citizens' higher GHG emissions.

\section{CONCLUSION}

With weights greater than $|5|$, our model suggests food production, renewable energy consumption, air transport, mobile cellular subscriptions, literacy rate, and population growth have the greatest impact on GHG emissions. These factors are indicators of industrialization and purchasing power. Thus, we reaffirm the importance of balancing economic growth and sustainable development. Governments could target market sustainable consumption, balanced diets, and environmental stewardship to this demographic.

Future studies should aim to determine if the correlations are causal. Due to the impracticality of conducting controlled experiments, future studies could analyze temporal precedence to more accurately determine if a factor caused an increase in GHG emissions per capita.

\section{ACKNOWLEDGEMENTS}

We would like to extend our sincerest thanks and appreciations to all those who helped made the big data challenge a possibility. We would like to recognize Mr. Artem Zaloga, Mr. Kieran DeFilippis, Mr. Ryan Poling, and Dr. Sacha Noukhovitch for their guidance and encouragement. We especially appreciate $\mathrm{Mr}$. DeFilippis's and Mr. Zaloga's knowledge, patience, and dedication in guiding us through this project.

\section{REFERENCES}

1. Pachauri R, Allen M, Barros V, Broome J, Cramer W, Christ R, et al. Climate change 2014: Synthesis report. contribution of working groups i, ii and iii to the fifth assessment report of the intergovernmental panel on climate change. IPCC [Internet]. 2014. Available from: http://ar5-syr.ipcc.ch/.

2. Levitus S., Antonov J. I., Boyer T. P., Locarnini R. A., Garcia H. E., Mishonov A. V. Global ocean heat content 1955-2008 in light of recently revealed instrumentation problems. Geophys. Res. Lett. 36 [Internet]. 2009. Available from: http://dx.doi. org/10.1029/2008GL037155. DOI 10.1029/2008GL037155. L07608.

3. Cook J, Oreskes N, Doran P, Anderegg W, Verheggen B, Maibach $E$, et al. Consensus on consensus: a synthesis of consensus estimates on human-caused global warming. Environ. Res. Lett. 11, 048002 [Internet]. 2016. Available from: http://stacks.iop.org/1748-9326/11/i=4/a=048002.

4. Speedy, A.Global production and consumption of animal source foods. J. Nutr. 133, 4048S-4053S [Internet]. 2003. Available from:http://jn.nutrition.org/content/133/11/4048S. 
short\#fn-1.

5. Gidon, E., Alon, S., Tamar, M. \& Ron, M. Land, irrigation water, greenhouse gas, and reactive nitrogen burdens of meat, eggs, and dairy production in the united states. Proc. Natl. Acad. Sci. United States Am. 111, 11996-12001 [Internet]. 2014. Available from: http://www.pnas.org/content/111/33/11996. full.

6. Adolescent pregnancy. WHO [Internet]. 2014. Available from: http://www.who.int/mediacentre/factsheets/fs364/en/.

7. Valin H, Havlík P, Mosnier A, Herrero M, Schmid E, Obersteiner M. Agricultural productivity and greenhouse gas emissions: trade-offs or synergies between mitigation and food security? Environ. Res. Lett. 8, 035019 [Internet]. 2013. Available from: http://stacks.iop.org/1748-9326/8/i=3/a=035019.

8. Satterthwaite, D. The implications of population growth and urbanization for climate change. Environ. Urbanization 21, 545-567 [Internet]. 2009. Available from:https://doi.org/10.1177/0956247809344361.DOI 10.1177/0956247809344361.

9. Hamit-Haggar, M. Greenhouse gas emissions, energy consumption and economic growth: A panel cointegration analysis from canadian industrial sector perspective. Sci. 34, 358-364 [Internet]. 2012. Available from: https://doi. org/10.1016/j.eneco. 2011.06.005.

10. World development indicators data. World Bank [Internet]. 2017. Available from: https://data.worldbank.org/indicator.

11. More than one-half of children and adolescents are not learning worldwide. United Nations Educ.Sci. Cult. Organ. [Internet]. 2017. Available from: http://uis.unesco.org/sites/ default/files/documents/fs46-more-than-half-children-notlearning-en-2017.pdf.

12. Metz, B., Davidson, O., Bosch, P., Dave, R. \& Meyer, L. Climate change 2007: Mitigation of climate change. contribution of working group iii to the fourth assessment report of the ipcc. Camb. Univ. Press. 463, 426-427. 2007.

13. Lassek, W. Why are we eating so much more than we used to? Pyschology Today [Internet]. 2012. Available from: www. psychologytoday.com/blog/why-women-need-fat/201205/ why-are-we-eating-so-much-more-we-used.

14. SAS Visual Analytics [Computer software] (2018). Retrieved from https://www.sas.com/en_ca/software/visual-analytics. html.
15. Scikit-learn machine learning Python library [Computer software] (2018). Retrieved from https://scikit-learn.org/ stable/. 